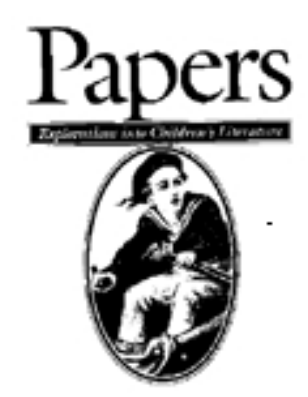

\title{
Digital Archives and Cultural Memory: Discovering Lost Histories in Digitised Australian Children's Literature 1851-1945
}

\author{
Michelle Dicinoski
}

\section{Queensland University of Technology}

The full-text digitisation of literary works can have some unexpected benefits for researchers in and outside of the field of literary studies. While the broader availability and easier distribution of the text is a clear and intended result of digitisation, the preservation of extra-textual material — such as bookplates, inscriptions, advertisements, and marginal notes-is an unintended result that can help to expand our knowledge of literary networks, reading practices, and cultural history. This kind of material was preserved by the Children's Literature Digital Resources Project (CLDR), which digitised nearly 600 works of early Australian children's literature-including poetry, short stories, novels, and picture books - that were first published during the period 1851-1945. The CLDR resources are available online through AustLit: The Australian Literature Resource (austlit.edu.au) ${ }^{1}$. This article will look closely at some of the material found in the CLDR texts, including evidence of the books' provenance (found in bookplates, book labels, inscriptions, and a handwritten letter), a newspaper clipping, and advertisements. Describing these discoveries can never be as informative as actually showing them, and for this reason, this essay has a companion online resource trail, 'Digital Traces of Past Lives: Bookplates, Inscriptions, and Ephemera Discovered in Digitised Books,' that guides readers through the digitised texts ${ }^{2}$. The discoveries are often surprising, moving, and unexpectedly informative. They remind us of the books' material lives, their previous owners, and their status as physical and cultural artefacts. They can also tell us a little about historical literary and artistic networks in Australia, and the position of children's book authors and illustrators within those networks. However, in order to make best use of these kinds of serendipitous discoveries, the infrastructure housing digital archives must be able to facilitate the search for this kind of material, as this article will go on to discuss.

In September 1899, the acclaimed children's book illustrator D.H. Souter inscribed a copy of his latest book, Bubbles, His Book, for the 29-year-old author Ethel Turner: 'With compliments Ethel Turner from D. Souter 6 Sep 99.' Turner would report in her journal for that day: 'Went to town, shopped - spring things. Saw Mr Souter about Gum Leaves [which Souter illustrated]. He gave me a copy of Bubbles, His Book, which he has illustrated really splendidly' (Turner 1979, p.190) ${ }^{3}$. Turner's Seven Little Australians had been published five years earlier, and Souter would illustrate five of Turner's books in total. Neither Turner nor Souter could have guessed that 43 years later, 
and seven years after Souter's death, Turner would herself re-inscribe the same copy of Bubbles, His Book to her granddaughter: 'Philippa Curlewis/ handed down to her as quite a precious book by Nan, who knew the artist, D. Souter \& thought a lot of his work/ Dec 1942.' Many years later, this very book would be donated to the National Library of Australia (NLA), where it would subsequently be digitised as part of the CLDR project in 2009 - and the two inscriptions would be digitised as well, and made available to readers online through AustLit.

Stories such as this one demonstrate why it is that digitisation has predicated a huge shift in conceptions of the archive, and of the nature of archival work. This shift has highlighted some of the complexities of cultural memory and the (artificial) divisions that have sometimes been drawn between personal and public histories. As Nancy Van House and Elizabeth F. Churchill argue, 'The facility with which material can be digitized, replicated and distributed

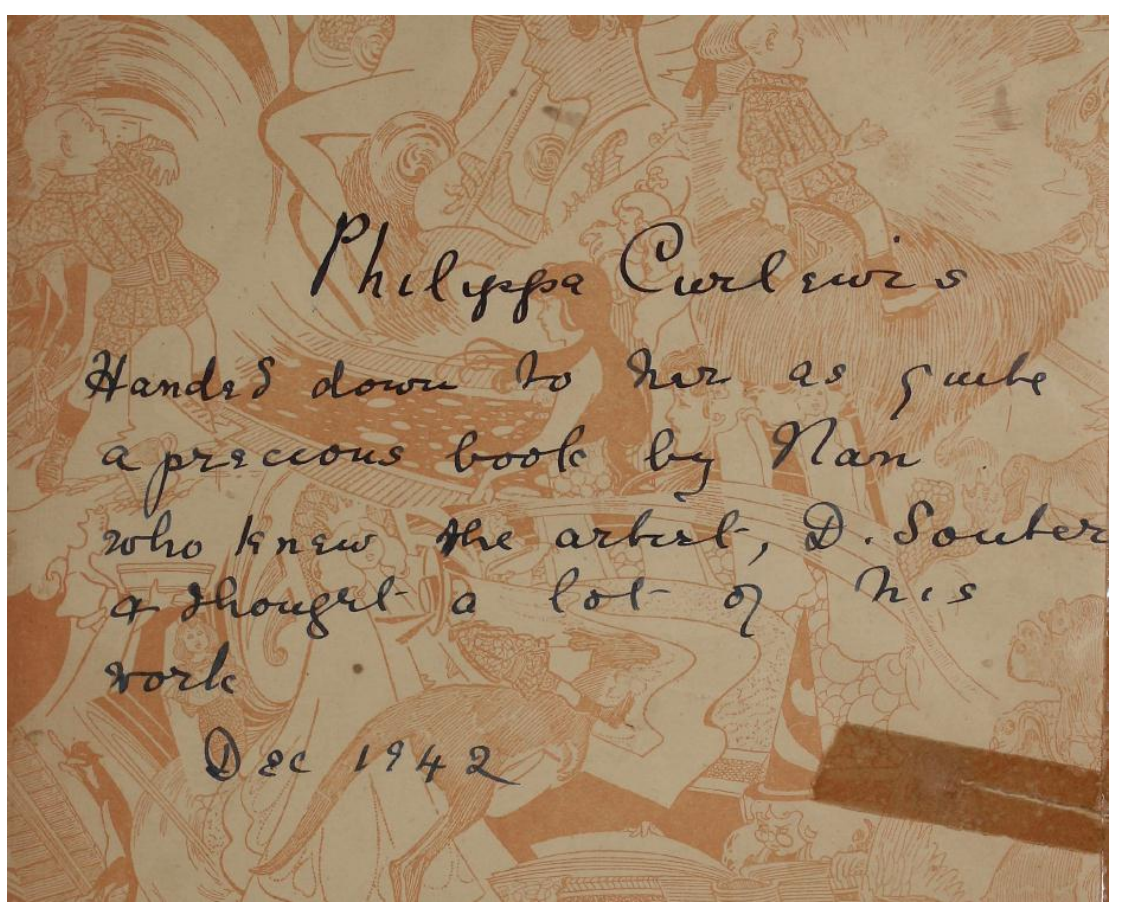
through and across socio-

Figure 1. Ethel Turner's inscription within her copy of Souter's Bubbles, His Book, which she presented to her granddaughter. technical networks has resulted in profound shifts in how we conceptualize memory, our personal and collective archive practices, and even our view of persistence and permanence' (Van House and Churchill 2008, p.296). It has also affected the ways in which we understand, store, and shape cultural memory. The term 'cultural memory' is sometimes a contested one (Eril 2011, p.1); Astrid Eril sees it as usefully defining 'the interplay of the present and the past in socio-cultural contexts' (p.2). For the purposes of this essay, and with specific reference to nation-based literature digitisation projects such as CLDR, the term 'cultural memory' will refer to a kind of communal memory that is both represented in and produced by the selection and digitisation of certain literary works. This kind of memory, like all forms of memory, can only ever be partial, subjective, and incomplete - but it is informative both because of and in spite of these reasons. For Marita Sturken, '[c]ultural memory as a term implies not only that memories are often produced and reproduced through cultural forms, but also the kind of circulation that exists between personal memories and cultural memories - the personal photograph, for instance, that ends up in the public arena' (Sturken 2008, p.74). The extra-textual material in the CLDR is interesting precisely because it highlights this circulation between personal and public memories, and individual and national histories, and because of the questions it raises about what should and should not be preserved as part of our shared cultural memory projects. 


\section{Bookplates, Book Labels, Inscriptions, and Other Traces}

If the CLDR's digitised books are relics from another time, so too are the bookplates that some of the books contain. Bookplates (also known as ex libris) are pictorial plates that are pasted into the frontmatter of books to identify them as belonging to the library of a collector. Historically, bookplates were custom designed for their owners, and the designers aimed to convey stylistically something about the owner's personal and professional interests, sometimes including motifs of personal significance to the owner. ${ }^{4}$

One example of an early Australian bookplate is found in the CLDR collection's The Bush Friends in Tasmania (1891), by Louisa Ann Meredith. The bookplate is that of Rex Nan Kivell, a New Zealandborn art dealer who spent most of his life in London. Born Reginald Nankivell, he 'resolutely discarded

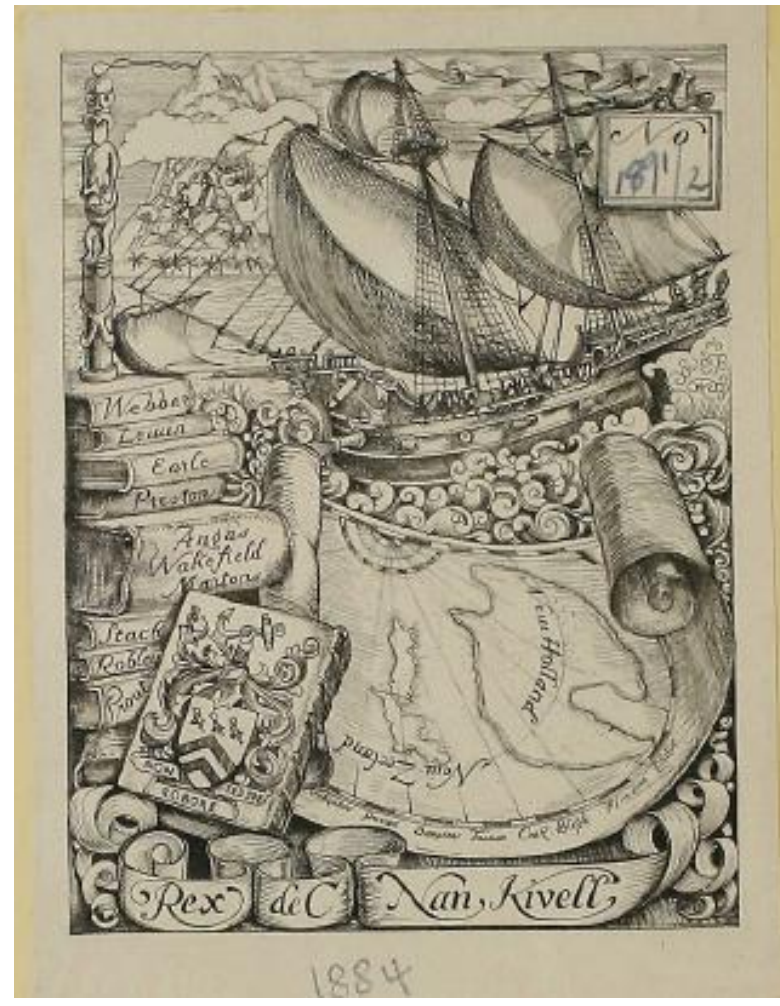

Figure 2. Rex Nan Kivell's bookplate his modest antipodean origins to emerge as an upand-coming gentleman art-dealer in London in the 1920s' (Thompson 2000, unpaged), re-making himself as Rex De Charembac Nan Kivell. It was at this time that he began to collect art, books, and manuscripts from Australia, New Zealand, and the Pacific. He eventually built an extensive collection of thousands of prints, books, and other items that he eventually sold to the NLA in 1959 - a remarkable acquisition for Australia, a country that Nan Kivell never visited. Meredith was an English-born, Tasmanian-based writer and botanical artist who documented Tasmania's flora in great detail across several books. The Bush Friends in Tasmania was published in a limited edition; the copy that was digitised by the CLDR project was signed by Meredith herself and numbered 177 out of 700 .

The CLDR contains another book from around the same era, The Voyage of the 'Monsoon' (1900), which has a bookplate that identifies its provenance as the library of Henry L. White. A pastoralist, White was also the uncle of novelist Patrick White, famously the first Australian to receive a Nobel Prize for Literature (in 1973). Henry White lived on the property Belltrees, near Scone, where he kept sheep and cattle. A man of many interests, he was also a philanthropist, a philatelist and an ornithologist. White's bookplate was designed by Lionel Lindsay, of the acclaimed Lindsay clan of artists and writers-Lionel's siblings Norman, Ruby, Percy, and Daryl were also artists, flourishing mainly in the first three decades of the $20^{\text {th }}$ century. Lionel designed numerous bookplates (including one for Australian Prime Minister Robert G. Menzies), many of which have been digitised by the NLA and can be viewed online. ${ }^{5}$ The Voyage of the Monsoon was also illustrated by 
D. H. Souter, an interesting coincidence that perhaps indicates the degree of interrelation in the Australian literary and artistic networks of the time.

While some of the works in the CLDR contain bookplates, many contain plainer plates that might more properly be termed book labels. These book labels are simpler, unillustrated, and appear in books that were won as prizes by children at school or Sunday School. Richard Rowe's Fred Leicester (1889), for example, was awarded to a Sidney Coward at Enmore Sunday School in 1907. The book label notes that Coward gained 122 out of 270 possible marks (which does make one wonder how the other children performed). Richard Rowe was an English writer who spent time in Australia and set some of his books here; for this reason, the CLDR digitised quite a number of his works, including Peter 'Possum's Portfolio (1858); The Lucky Bag (1876); A Child's Corner Book (1876); The Tower on the Tor (1876); and Roughing it in Van Diemen's Land (1880). The digitised version of Rowe's A Holiday Book: Stories for the Young (1877) contains a bookplate inscribed: 'Presented to Dick Rowe, with his Father's love.' Did the boy's father buy the book because his son shared the author's name? This is just one of the many questions provoked by the CLDR collection.

While these discoveries are delightful, it is also worth noting some of the collection's more conspicuous absences. CLDR digitised out-of-copyright works, or works that were in copyright, but for which permission to digitise was granted by rights-holders. Some of the most iconic Australian children's books from the period 1851-1945 (such as Turner's Seven Little Australians and Mary Grant Bruce's Billabong series) were not able to be included in the collection precisely because of their enduring popularity: they remain in copyright and in print to this day. Copyright remains in place for all works published after 1954. The copyright term in Australia was extended in 2004 to cover the life of the author plus 70 years; it was previously life plus 50 years. Thus all of the works by Ethel Turner and Mary Grant Bruce, both of whom died in 1958, are all in copyright and their works retain commercial value. More likely to be given the rights-holders' permission for digitisation were less well-known works that are out of print but still in copyright. In fact, rightsholders were often keen in these instances for digitisation to occur. It is also worth noting that while these digital traces of personal and cultural history can provide striking insights into the past, they will generally be drawn from the middle and upper classes, those who not only possess the resources to buy books, but also to preserve them in personal libraries, and who also later donate their books to collections such as the NLA's.

\section{Personal and National Histories, Digitisation, and Cross-Database Searching}

Our knowledge about the CLDR collection and its texts' former owners may well increase as more public (and private) records are digitised and made widely available online. In some cases, it is already possible to discover a surprising amount about the histories of these books by drawing on simple web searches. An example is Etheldred Waddy's The Camerons of Niddry (1904), a copy of which was presented to a student named Gilbert Berryman as a first prize for 'lessons' at St Mary's School, Burra. It's not clear in which year he was presented his prize, just that he was in Class III. But other digital traces of Gilbert Berryman exist, and we can learn quite a lot about his life. The website of the Australian Defence Force Academy provides access to a database of information 
about the (First) Australian Imperial Force (AIF) of World War I, compiled by military historian Professor Peter Dennis. A database search reveals that Berryman was educated at Burra Burra Public School in South Australia, and Superior Public School in Bondi, New South Wales. He enlisted in the AIF in January 1916, at the age of 21. Tragically, Berryman was fatally wounded in France in 1917. The Australian War Memorial website has a digitised report (handwritten and typewritten) from a nurse who cared for him at Epsom Hospital. The report states that Berryman suffered a head wound, and while he initially seemed to be improving in hospital, his condition worsened and he died on the $27^{\text {th }}$ of June 1917. The nurse is careful to note that 'at the end, he suffered little or no pain and was a most cheerful and grateful patient', and that he had friends with him at the time of his death. The letter states that Berryman is buried 'at Brookwood Cemetery, Near London.'.

Still further information comes to light if we search the NLA via its 'Trove' service, an integrated 'discovery service' that enables users to search across a wide range of Australian libraries, galleries, archives, museums, and digitised material. A Trove search for information on Gilbert Berryman produces a notice of his death in the Burra Record of 11 July 1917. The newspaper column contains news of other soldiers from the region who had been wounded, promoted, or captured at around the same time.

This is perhaps one of the more striking and unprecedented tools that digital archives provide us: the capacity to undertake these kinds of searches, and to establish such unexpectedly public evidence of an otherwise private life. Sturken reminds us that '[c]ultural and individual memory are constantly produced through, and mediated by, technologies of memory' (p.75). When the CLDR team began building this literary archive, they knew they were creating one kind of memory, but could never have imagined the lives of book readers and owners would also be preserved in this way, and connect up with other digital traces.

Some of the books in the CLDR collection are inscribed with dedications, or simply with their owner's name. The Enchanted Evening (1920) is dedicated 'to Lily from Santa Claus 1940.' S.G. Fielding's The Southern Light (1895) was owned by Max Dupain when he was a school student. Dupain went on to become one of Australia's most famous photographers, and is most noted for his pictures of people on Bondi Beach. He has written his contact details in the book: 'Maxwell S. Dupain, Sydney Grammar School, College St, City. January 1929.' Other works have unexpected additions. The Lady of the Blue Cloak (1919) is an illustrated fairy story that was written by Paula Fitzgerald and illustrated by Agatha Fitzgerald. The copy that was digitised was evidently sent to George Robertson, the co-founder of the publishing company Angus \& Robertson, by Sydney Ure Smith, one of the editors of Art in Australia. Ure Smith sent a letter to Robertson along with the book, and that letter, too, has been digitised.

In the letter, dated December 1919, Ure Smith writes that he is impressed with Agatha Fitzgerald's illustrations, and recommends her in a professional capacity to Robertson, suggesting that she might produce artwork for Angus \& Robertson, perhaps for Christmas publications. Smith adds that he had hoped Fitzgerald would work for Art in Australia-'but alas: she is to be married-so that 
really she will only have time in the near future to illustrate A \& R's publications.' This is a fascinating document for what it reveals about the networks in which Fitzgerald, Ure Smith, and

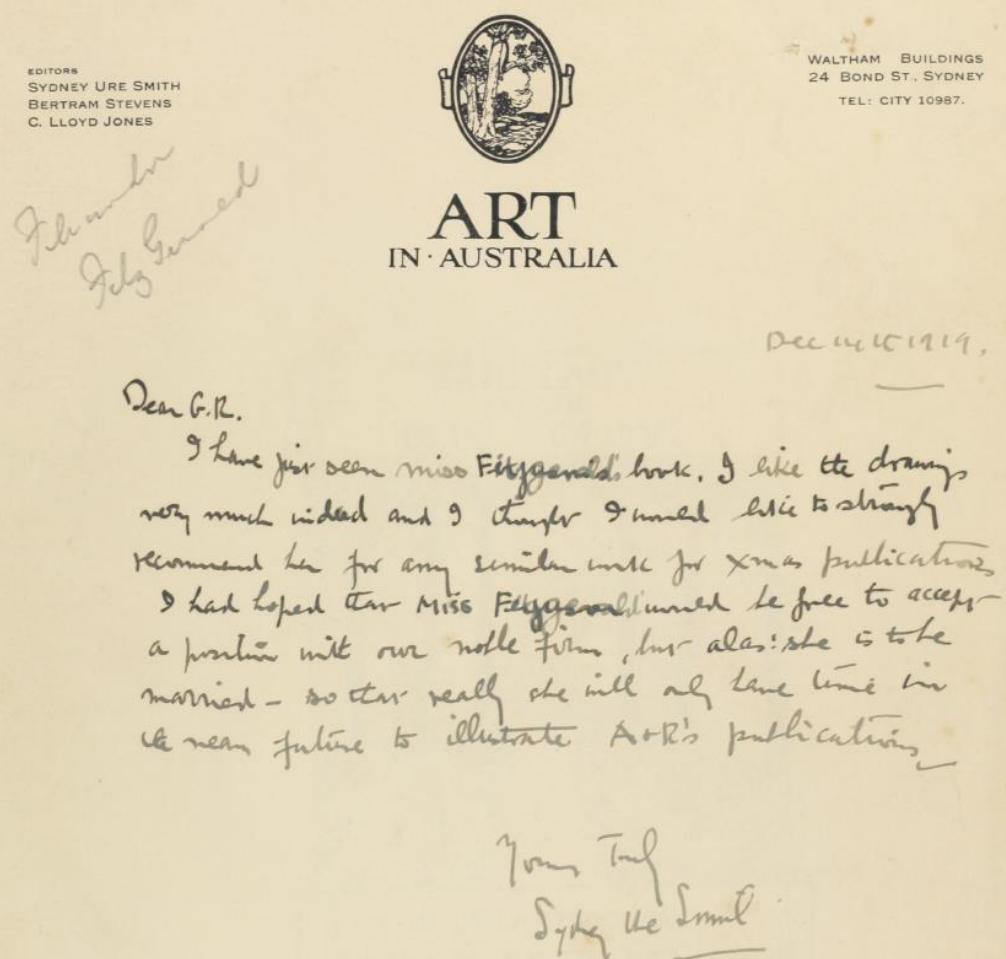

Figure 3. Sydney Ure Smith's letter to George Robertson regarding the illustrator Agatha Fitzgerald.

Robertson were operating. As

Joseph R. Nicholson points out, '[s]ignatures and dedications of friends and colleagues on title pages trace the tangled network of writers' relationships with other writers and help identify their place in the larger literary culture in which they lived and wrote' (Nicholson 2010, p.108). It also demonstrates the constraints placed on women workers due to gender inequalities in the workforce.

Another CLDR text, The Bush Boys' Book (1911) provides information and advice on practical matters pertaining to camping, fire building, and other elements of bushcraft. Curiously, in the section on camping, a newspaper clipping has been left inside. Now yellowed, but still perfectly intact, it details the death of Edward Wallis Crossley, 'brother of Madam Ada Crossley, the wellknown singer.' Crossley and his son had been camping in his car, which had become bogged in a remote area. A falling tree had landed on the car and killed Crossley, leaving his son unharmed. Cross-checking Trove for digitised newspaper articles reveals that the accident occurred in April 1925. Also interesting is the significant amount of advertising that the book contains, even on its back cover. Boot polish, cook stoves, guns and canoes are all advertised in the back of The Bush Boys' Book, along with J. Scott's bait and tackle business, which spruiks 'sandworms, shrimp, fishing, tackle - 'write for price list', the advertisement urges, and 'mention 'Bush Boy's Book' [sic] when writing for list.' Advertising is an important part of our cultural history, and this kind of advertising is striking not only for its appeal to the child-consumer, but also for its evocative depiction of a time long since passed. Other advertising from around this time targeted parents, rather than children, and promoted, for example, the Union Bank of Australia, cod liver oil, MacRobertson's Milk Kisses, George Farmer's Ballarat Hams and Bacon, and Weingarten's 'ErectForm' Corsets (As in the 1905 work Her Royal Highness Queen Bee).

When we consider the archive, we often think about the past. What kinds of past are we to preserve, we wonder, and how are we to determine an item's significance? But Jacques Derrida argues in Archive Fever that 
the question of the archive is not, we repeat, a question of the past [...] It is a question of the future, the question of the future itself, the question of a response, of a promise and a responsibility for tomorrow. The archive: if we want to know what that will have meant, we will only know in times to come. Perhaps.

(1996, p.36)

This is why questions of how and what we archive are so important and also so difficult to answer. The 'meanings' of the archives that we create only ever present themselves in the future, and we can only ever build them in the past.

\section{Digitisation Methods and their Implications for Access}

Digitisation programs such as AustLit's ongoing program to digitise Australian literature enable researchers far greater access to rare and old books and ephemera than was ever previously possible. It is access that can occur easily, from a distance, and without the need for handling the physical document, which might be fragile, or valuable, or both. But digitisation alone does not ensure that books and ephemera can be easily accessed by researchers. The searchability of a digital text is significantly affected by how it is digitised, which parts of it are digitised, and how the text and its extra-textual material are subsequently tagged in the database or archive that houses it. Additionally, predicting and planning for this kind of extra-textual material is impossible, because it only becomes evident during and after the digitisation process - and only under close inspection from digitisation staff, researchers, librarians and archivists. Close inspection of the digitised material is essential for the discovery of evidence of provenance, marginalia, and ephemera that might not previously have been recorded. Careful recording of what is found is essential for researchers' continued awareness of the material's existence.

In 2008, when the CLDR project had digitised just 75 texts, chief investigators Kerry Mallan and Annette Patterson wrote: 'The value of the CLDR project lies in its goal to provide a comprehensive, searchable body of texts (fictional and critical) to researchers across the humanities and social sciences' (Mallan and Patterson 2008, unpaged). While this is certainly true, what the researchers didn't predict was the additional value created by the inadvertent digitisation of marginalia, inscriptions, bookplates and other matter. These were preserved because the digitisation method chosen reproduced the texts in full colour in a kind of photographic file. The CLDR team, in consultation with AustLit, chose this kind of digitisation because so many of the CLDR's texts are illustrated, often in very fine detail, and some are even hand-written. The team's choice of digitisation meant that all marginal notes, bookplates, advertising, rips, scribbles, colouring-in, and age spots would also be permanently preserved. The team also specified that texts be digitised from cover to cover, which, crucially, resulted in the digitisation of many advertisements and publisher catalogues that would otherwise be easily overlooked. What's more, because the digitisation process used optical character recognition (OCR) technology to automatically convert images to text, these catalogues and advertisements (as well as the full-texts themselves, of course) are also searchable by keyword in the AustLit database. There are lessons to be learned here for other digitisation projects about the nature of the digitisation process itself, the technology used, and how 
these technical choices may affect how closely a digital text resembles the physical text that it purports to reproduce.

The usability and searchability of information in digital collections is also affected by how the digitised item is subsequently catalogued or indexed by the database or other infrastructure that houses it. For example, Shafquat Towheed has observed that while the Internet Archive has digitised a huge number of out-of-copyright texts, 'as well as potentially a wealth of information (in the form of marginalia, book plates, marks of ownership, and borrowing stamps) about how these books might have been read' (Towheed 2010, 140), this kind of 'ancillary data is disaggregated and accidental; it has not been tagged, recorded, or marked-up, and cannot be searched or examined in any systematic way' (140). This is also true of much of the 'ancillary data' in the CLDR texts. The works are indexed according to AustLit's long-standing and sophisticated methods of dealing with bibliographic data. However, in the AustLit domain, works are categorised mainly in terms of their publication details. The information that is recorded about an individual digitised text relates to how it operates as one of hundreds or thousands in an edition.

The AustLit data model is based on the International Federation of Library Associations' (IFLA) Functional Requirements for Bibliographical Records (FRBR) and is concerned with the abstract description of books and other published items (see Kilner 2005). AustLit's implementation of the FRBR is very flexible but, for practical reasons, does not usually describe an individual item; however, as Kerry Kilner has detailed, 'item-level information'-such as annotations or specific library housing information - may be listed in the work's AustLit record $(2005,89)$. While the AustLit search infrastructure has not previously been designed for adding or seeking information about marginalia or bookplates, this is something that AustLit's digitisation programme now must consider. This one example is indicative of some of the broader challenges facing book history scholars and others in this new digital environment: in storing information, we must endeavour to consider every kind of material that we are preserving (and how it may be searched for), as well as attempting, at least in some sense, to predict future database architecture and technical possibilities. AustLit is currently moving towards a model that draws on volunteers' contributions to perform tasks such as annotation and tagging of content in line with their own expertise, which should ensure that this kind of descriptive work is carried out more extensively than is currently possible.

Researchers have noted the importance of chance discoveries in historical research. A small but significant number of discoveries are made via a serendipitous sighting while browsing library catalogues or shelves, for example (Dalton and Charnigo 2004; Quan-Hase and Martin 2012). Extra-textual information such as that digitised by the CLDR project is both an example of this kind of serendipity, and a useful case for examining how we may engineer the 'serendipitous' discovery of this information by other researchers. For instance, tagging it all as extra-textual material might increase search- and browsability, thus making it more possible for researchers to stumble upon it. This would require detailed indexing of bookplates and book labels, notes, library cataloguing information, booksellers' stamps and stickers, and any other material. But such indexing takes time (and, therefore, money) — not only to index what is found, but also to closely examine the digitised 
works in the first place - and also requires a standardised vocabulary for classifying the extratextual matter, as well as an understanding of what is significant in the first place. As Lundy has noted in his discussion of best-practice cataloguing of evidence of provenance in special collections, 'neither the books nor the former owners have to be rare or famous to make worthwhile the effort of cataloguers to record provenance information and make it searchable in bibliographic records' (2008, 171). However, the nature of the items preserved by the NLA-items perceived to be culturally valuable, in some cases because of who owned or collected them - increases the chances that a serendipitous discovery will occur, especially in terms of discoveries about literary networks.

All of these considerations remind us that when we make a digital version of an existing text, we actually create a new kind of text. Marlene Manoff, Associate Head of MIT's Humanities Library, points out that

When studying the history of the book, attention to materiality means analysing such things as typography, binding illustrations, and paper to understand their role in the creation of meaning. In a world of digital artifacts, textual scholars may consider a whole new range of physical objects and process, including platforms, interfaces, standards, and coding.

(Manoff 2006, 312)

When digitising texts, then, and making a digital text from a physical copy of a text, it benefits us to think about not just how the digital version replicates the original, but also how it departs from it. The digitisation of this kind of material broadly disperses new forms of knowledge about print cultures of the past. It also opens new avenues for research. Manoff suggests that 'the nature of the research experience we are providing is transforming the ways in which study and research are conducted, even as it is changing the kinds of knowledge being produced' (323). As these transformations take place, we face a range of opportunities, and a range of choices. What is certain is that within the pages of our books lie even greater riches than we have previously been able to discover.

\section{Endnotes}

${ }^{1}$ Based at Queensland University of Technology (QUT), the CLDR project digitised texts that were drawn from the stacks at Deakin University, Monash University, the National Library of Australia, QUT, the State Library of Victoria, and The University of Queensland. Without the generosity of these institutions in making the books available to the CLDR team, this project could not have taken place.

${ }^{2}$ This trail is available at

AustLit: http://www.austlit.edu.au/run?ex=ShowTrail\&trailId=BCE1D2F84DA728D1.

${ }^{3}$ Interestingly, Souter has signed his note ' 6 Sep 99', but Turner records their meeting as taking place on September 4 of 1899. The reason for this discrepancy is unclear. It is worth noting that Philippa Curlewis, Turner's granddaughter, would go on to compile her grandmother's diaries for their publication decades later (as Philippa Poole). 
${ }^{4}$ John Lane Mullins, President of the Australian Ex Libris Society, said in 1925 that regardless of the skill of the artist or the beauty of the design, a bookplate fails its purpose if it is not custom made to visually express something of the qualities of its owner. 'A close relation between subject and owner is essential,' he argued, 'something expressive of aspirations, ideals or pursuits... a bookplate ought at the same time adorn the book in which it is pasted' (Croll 141).

${ }^{5}$ These bookplates can be viewed at http://nla.gov.au/nla.pic-an11056071.

\section{Acknowlegements}

The CLDR Project was supported by grants from the Australian Research Council's Linkage, Infrastructure, Equipment and Facilities scheme and from QUT. It was carried out with the support of and in conjunction with Austlit: The Australian Literature Resource. I would like to thank Kerry Mallan, Kerry Kilner, Carol Wical, Amy Cross, and Cherie Allan for their feedback on early drafts of this essay.

\section{References}

Croll, R.H. (1948) 'The bookplate and Australia', Across the Years: The Lure of Early Australian Books. Ed. Charles Barrett. Melbourne: N.H. Seward. 141-148.

Dalton, M. Stieg and Charnigo, L. (2004) 'Historians and their information sources', College \& Research Libraries 65, 5, 400-424.

Derrida, J. 1996 [1995] Archive Fever: A Freudian Impression. Trans. Eric Prenowitz. Chicago: U of Chicago P.

Erll, A. and Nünning, A. (eds) (2008) Cultural Memory Studies: An International and Interdisciplinary Handbook. With S. B. Young. Berlin; New York: Walter de Gruyter.

Kilner, K. (2005) 'The AustLit Gateway and Scholarly Bibliography: A specialist implementation of the FRBR', Cataloguing \& Classification Quarterly 39,3-4, 87-102.

Lundy, M. Winslow. (2008) 'Provenance evidence in bibliographic records: Demonstrating the value of best practices in special collections cataloging', Library Resources \& Technical Services 52,3, 164-172.

Mallan, K. and Patterson, A. (2008) 'Present and active: Digital publishing in a post-print age', $M / C$ 11,4. Available from: http://journal.mediaculture.org.au/index.php/mcjournal/article/viewArticle/40 [Accessed 20 March 2010].

Nicholson, J. R. (2010) 'Making personal libraries more public: A study of the technical processing of personal libraries in ARL institutions', RBM: A Journal of Rare Books, Manuscripts, and Cultural Heritage 11,2, 106-133.

Manoff, M. (2006) 'the materiality of digital collections: theoretical and historical perspectives', Portal: Libraries and the Academy 6,3, 311-325.

Quan-Haase, A. and Martin, K. (2012) 'Digital humanities: The continuing role of serendipity in historical research', iConference 2012. February 7-10, 2012, Toronto, Ontario, Canada.

Sturken, M. (2008) 'Memory, Consumerism, and media: Reflections on the emergence of the field', Memory Studies 1, 73-78. 
Thompson, J. R. [2000] 'Sir Rex De Charembac Nan Kivell', Australian Dictionary of Biography. National Centre of Biography, Australian National University. Available from

http://adb.anu.edu.au/biography/nan-kivell-sir-rex-de-charembac-11219/text20003 [Accessed Januray 30 2012]

Towheed, S. (2010) 'Reading in the digital archive', Journal of Victorian Culture. 15, 1, 139-143.

Turner, E. (1987) [1979] The Diaries of Ethel Turner. Compiled by Philippa Poole. Sydney, Collins.

Van House, N. and Churchill, E. F. (2008) 'Technologies of memory: Key issues and critical perspectives', Memory Studies 1, 295-310.

\section{SOCR}

\section{Biographical Note}

Michelle Dicinoski is a researcher and a writer. She works for Queensland University of Technology on the Asian-Australian Children's Literature and Publishing project and the CLDR project, and has previously worked on other AustLit projects. She has a $\mathrm{PhD}$ in creative writing, and is the author of the poetry collection Electricity for Beginners (Clouds of Magellan, 2011) and the memoir Ghost Wife (Black Inc., 2013). 